\title{
THE CENOZOIC DIVERSITY OF ANTARCTIC BIVALVES DOES NOT REFLECT SOUTHERN OCEAN ENVIRONMENTAL CHANGES AFTER THE ANTARCTIC THERMAL ISOLATION
}

\author{
Fernanda Quaglio $^{1 *}$, Luiz Eduardo Anelli ${ }^{1}$, Paulo Roberto dos Santos ${ }^{1} \&$ Lucas Veríssimo Warren $^{1}$ \\ ${ }^{1}$ Departamento de Geologia Sedimentar, Instituto de Geociências, Universidade de São Paulo (IGc-USP). Rua do Lago, 562. CEP: 05508-080. \\ Cidade Universitária, São Paulo, Brasil. \\ E-mail: quaglio@usp.br*
}

\begin{abstract}
Environmental changes occurred in Southern Hemisphere in response to the separation of Antarctica from Australia, around Eocene/Oligocene boundary, and from South America, during the late Oligocene, greatly affected biodiversity in Southern Ocean. Although it is generally accepted that the Antarctic thermal isolation affected the Cenozoic biodiversity by changing environmental conditions, there is no available study concerning the Cenozoic dynamics of Antarctic bivalve diversity in relation to climatic changes. In this study, an assembling of all available bivalve family and genera described from Antarctic Cenozoic deposits as well as modern bivalve family and genera were analyzed in order to evaluate possible effects of Cenozoic environmental changes on Antarctic bivalve diversity along the Cenozoic. The main conclusion of this work is that the currently known Cenozoic record of the Antarctic bivalves does not reflect Cenozoic environmental changes. This is probably related to the restricted record of Antarctic bivalves, and therefore to the scarce knowledge on the Cenozoic diversity of the group. The analysis also revealed that Cenozoic intervals of highest diversity are attributed to few areas in Antarctica that are available for paleontological exploration. Besides, the large number of recorded bivalve taxa in some Cenozoic intervals may be related to the stratigraphic control of deposits.
\end{abstract}

Key-words: Antarctica, Southern Ocean, bivalves, diversity, paleoecology, Cenozoic.

\section{RESUMO}

A DIVERSIDADE CENOZÓICA DOS BIVALVES ANTÁRTICOS NÃO REFLETE AS MUDANÇAS AMBIENTAIS DO OCEANO AUSTRAL APÓS O ISOLAMENTO TÉRMICO DA ANTÁRTICA. As mudanças ambientais ocorridas no Hemisfério Sul em resposta à separação da Antártica e a Austrália, no limite Eoceno/Oligoceno, e da Antártica e a América do Sul, durante o final do Oligoceno, afetaram profundamente a biodiversidade das regiões do Oceano Austral. Muito embora seja amplamente aceito que o isolamento térmico da Antártica influenciou a biodiversidade ao alterar as condições ambientais da região, não há estudos relacionados à dinâmica de diversidade dos bivalves antárticos frente às mudanças climáticas ao longo do Cenozóico. No presente estudo, foi analisado o números de famílias e gêneros de bivalves fósseis descritos em depósitos cenozóicos da Antártica, bem como o número de famílias e gêneros de bivalves modernos, com o objetivo de avaliar possíveis efeitos das mudanças ambientais ocorridas ao longo do Cenozóico na diversidade dos bivalves antárticos. Como principal conclusão deste trabalho, o conhecimento atual sobre os bivalves cenozóicos da Antártica não reflete as mudanças ambientais ocorridas ao longo do Cenozóico. Isto provavelmente está relacionado ao registro limitado dos bivalves antárticos e, conseqüentemente ao conhecimento incipiente da diversidade cenozóica do grupo. A análise revelou também que os intervalos de tempo de maior diversidade são, na realidade, resultantes de estudos realizados nas poucas áreas de rochas aflorantes disponíveis para exploração paleontológica na Antártica. No entanto, o grande número de táxons de bivalves registrados em alguns intervalos do Cenozóico pode estar relacionado ao controle estratigráfico dos depósitos.

Palavras-chave: Antártica, Oceano Austral, bivalves, diversidade, paleoecologia, Cenozóico. 


\section{INTRODUCTION}

Southern Hemisphere experienced profound environmental changes during latest Cretaceous and Cenozoic times due to the reorganization in tectonics, oceanography, climate and atmospheric circulation, which greatly affected the Southern Ocean biotic evolution to the present day patterns (Bartek et al. 1992, Exon et al. 2001, Barker \& Thomas 2004). These changes took place specially in response to the geographic and thermal isolation of Antarctica, due to the separation of Antarctica from Australia, around Eocene/Oligocene boundary (Exon et al. 2001), and from South America, during the late Oligocene (Barker \& Thomas 2004, Livermore et al. 2004). The separation of Antarctica from Australia, following the Tasmanian Gateway opening, triggered the circulation of cold marine currents from Western Australia towards South America (Exon et al. 2001). The separation of Antarctica from South America, following the Drake Passage opening, allowed the flowing of these cold currents around Antarctica and the Circum-Antarctic Current establishment (Eagles \& Livermore 2002, Barker \& Thomas 2004, Pfuhl \& McCave 2005).
Antarctic thermal isolation was a direct effect of the geographic isolation, and is represented by modern ice sheets that cover virtually the entire continent. The thermal isolation is also related to feedback factors, as marine and atmospheric currents, as well as albedo effects and drop in atmospheric $\mathrm{CO}_{2}$ (Bartek et al. 1992, Zachos et al. 2001, DeConto \& Pollard 2003a, b, Barker \& Thomas 2004, Tripati et al. 2005).

Although it is widely accepted that the Antarctic thermal isolation affected the Cenozoic biodiversity by changing environmental conditions, especially paleobiogeographic distribution, there is no available study concerning the Cenozoic dynamics of Antarctic bivalve diversity related to climatic changes. This work represents a first approach to the Cenozoic diversity of bivalve genera and families from Antarctica, in order to evaluate possible environmental change effects on the bivalve diversity evolution during the Cenozoic in Antarctic region.

\section{COMPARISON AND DISCUSSION}

Table I summarizes bivalve taxa so far described from Antarctic Cenozoic deposits. All referred localities are plotted in Figure 1.

Table I. Family, genus and species numbers of Antarctic bivalve showed according to geological units (U) and as total numbers (T) recorded for each Cenozoic interval (data from Zinsmeister 1984, Pugaczewska 1984, Gaździcki \& Pugaczewska 1984, SOMBASE, Stilwell \& Zinsmeister 1987, 1992, 2000, Stilwell et al. 2004, Zinsmeister \& Macellari 1988, Studenka 1991, Stilwell 2000, 2002, 2003, Jonkers 2003, Anelli et al. 2006, Quaglio et al. in press).

\begin{tabular}{|c|c|c|c|c|c|c|c|c|}
\hline \multirow{2}{*}{ Epoch } & \multirow{2}{*}{ Unit } & \multirow{2}{*}{ Locality } & \multicolumn{2}{|c|}{ Family } & \multicolumn{2}{|c|}{ Genus } & \multicolumn{2}{|c|}{ Species } \\
\hline & & & $\mathbf{U}$ & $\mathbf{T}$ & $\mathbf{U}$ & $\mathbf{T}$ & $\mathbf{U}$ & $\mathbf{T}$ \\
\hline Recent & - & - & - & 27 & - & 46 & - & 118 \\
\hline Holocene & Taylor Fm. & Ross Sea & 1 & 1 & 1 & 1 & 1 & 1 \\
\hline Pleistocene & Victoria Land Basin & Victoria Land & 1 & 1 & 1 & 1 & 1 & 1 \\
\hline \multirow{2}{*}{ Pliocene } & Cockburn Island Fm. & Cockburn Island & 2 & \multirow{2}{*}{2} & 3 & \multirow{2}{*}{3} & 3 & \multirow{2}{*}{4} \\
\hline & Sorsdal Fm. & Victoria Land & 1 & & 1 & & 1 & \\
\hline \multirow{5}{*}{ Miocene } & Cape Melville Fm. & King George Island & 7 & \multirow{5}{*}{7} & 7 & \multirow{5}{*}{8} & 8 & \multirow{5}{*}{11} \\
\hline & Hobbs Glacier Fm. & James Ross Island & 1 & & 1 & & 1 & \\
\hline & Drygalski Fm. & Heard Island & 1 & & 1 & & 1 & \\
\hline & Victoria Land Basin & Victoria Land & 1 & & 1 & & 1 & \\
\hline & Victoria Land Basin & Victoria Land & 1 & & 1 & & 1 & \\
\hline \multirow{2}{*}{ Oligocene } & Polonez Cove Fm. & King George Island & 16 & \multirow{2}{*}{16} & 24 & \multirow{2}{*}{24} & 29 & \multirow{2}{*}{33} \\
\hline & Destruction Bay Fm. & King George Island & 2 & & 2 & & 4 & \\
\hline \multirow{2}{*}{ Eocene } & La Meseta Fm. & Seymour Island & 20 & \multirow{2}{*}{26} & 26 & \multirow{2}{*}{47} & 34 & \multirow{2}{*}{58} \\
\hline & erratic blocks & McMurdo Sound & 19 & & 30 & & 31 & \\
\hline Paleocene & Sobral Fm. & Seymour Island & 10 & 10 & 12 & 12 & 13 & 13 \\
\hline \multirow[b]{2}{*}{ Cretaceous } & Snow Hill Island Fm. & Cockburn Island & 8 & \multirow[b]{2}{*}{22} & 8 & \multirow[b]{2}{*}{27} & 8 & \multirow[b]{2}{*}{34} \\
\hline & $\begin{array}{c}\text { López de Bertodano } \\
\text { Fm. }\end{array}$ & Seymour Island & 22 & & 26 & & 28 & \\
\hline
\end{tabular}



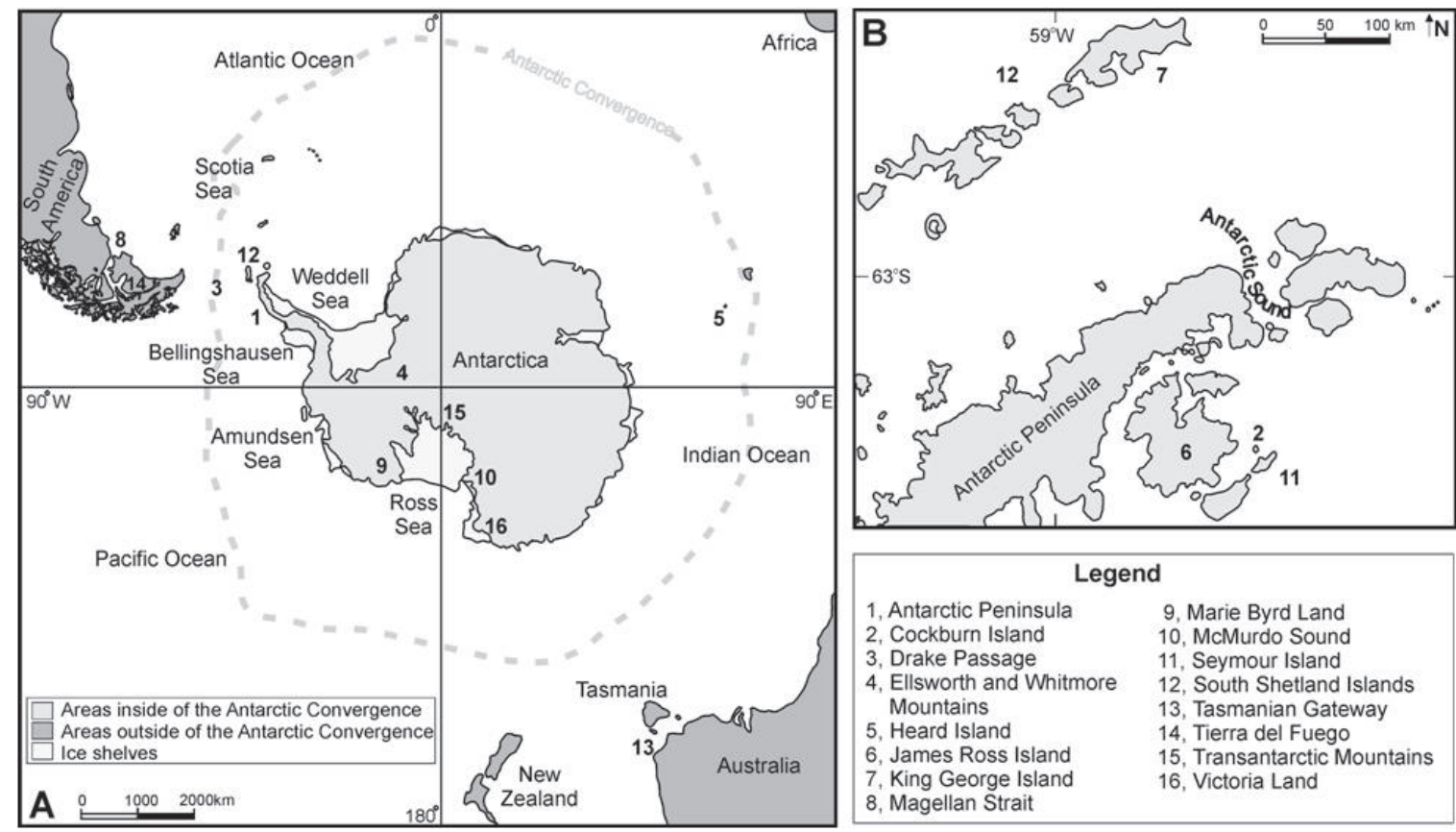

Figure 1. Localities referred in the text and table. A) South Pole azimuthal equidistant projection of areas within the Antarctic Convergence and periphery. B) Antarctic Peninsula. (compiled from Zinsmeister 1982 and projection from J.P. Rodrigue, Hofstra University, Hempstead, New York.)

According to Table I most Cenozoic bivalve taxa are recorded in Eocene deposits of the La Meseta Formation at Seymour Island, and in erratic blocks collected in McMurdo Sound region (Figure 1). Oligocene is the second time interval with large number of bivalve records, mainly from the Polonez Cove Formation at King George Island (Figure 1).

Data from Table I was plotted in Figure 2, with the intention of evaluating the Cenozoic diversity of Antarctic bivalves.

In order to compare, another diversity graphic was generated (Figure 3) by plotting bivalve genera and families recorded in Cenozoic deposits from New Zealand with data gathered by Beu \& Maxwell (1990). New Zealand bivalve record is the better-known and studied of all Southern Ocean regions and, for this reason, is appropriate in studies related to Antarctic bivalves.

According to the Figure 3, the number of bivalve families in New Zealand remained almost constant after the Eocene, while the number of genera increased from the late Eocene to the late Miocene, and rather decreased in the Holocene.

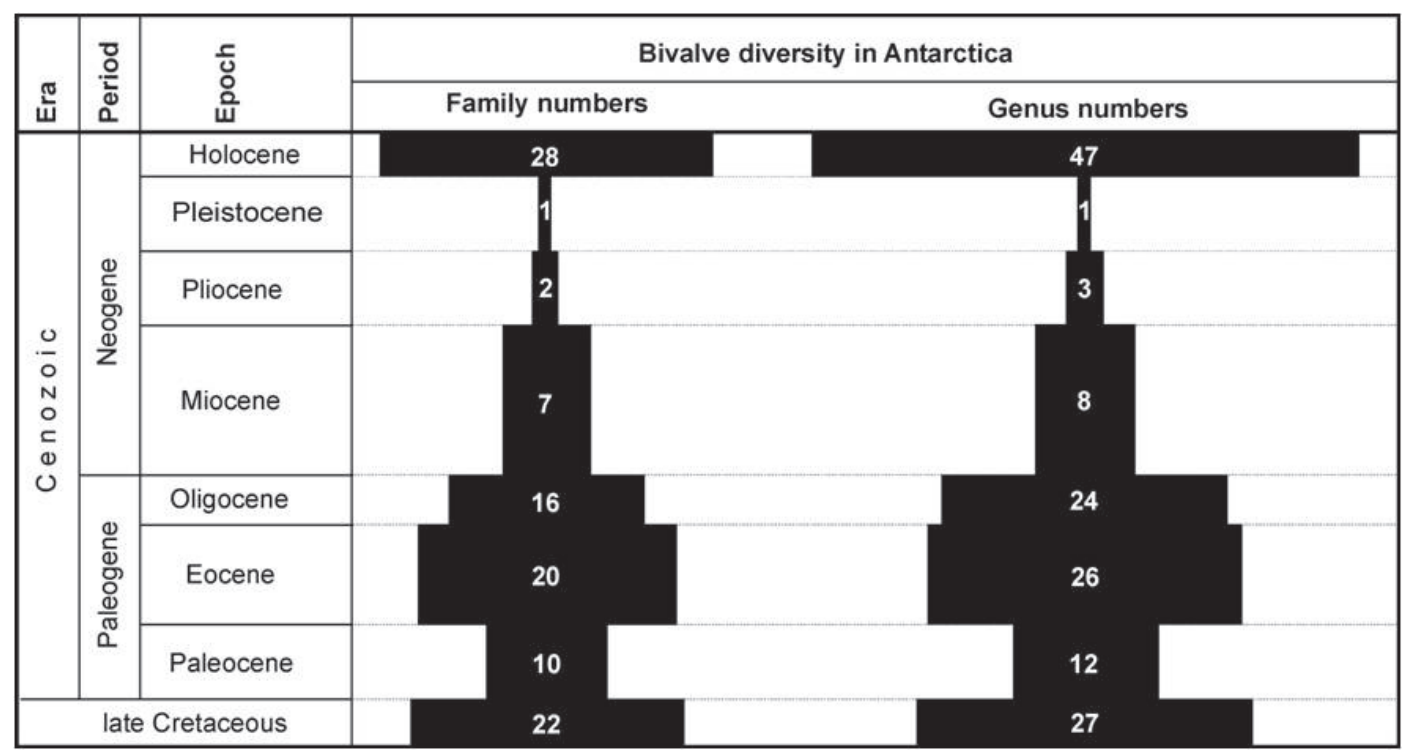

Figure 2. Cenozoic diversity of Antarctic bivalves, according to family and genus numbers (data from Table I). 


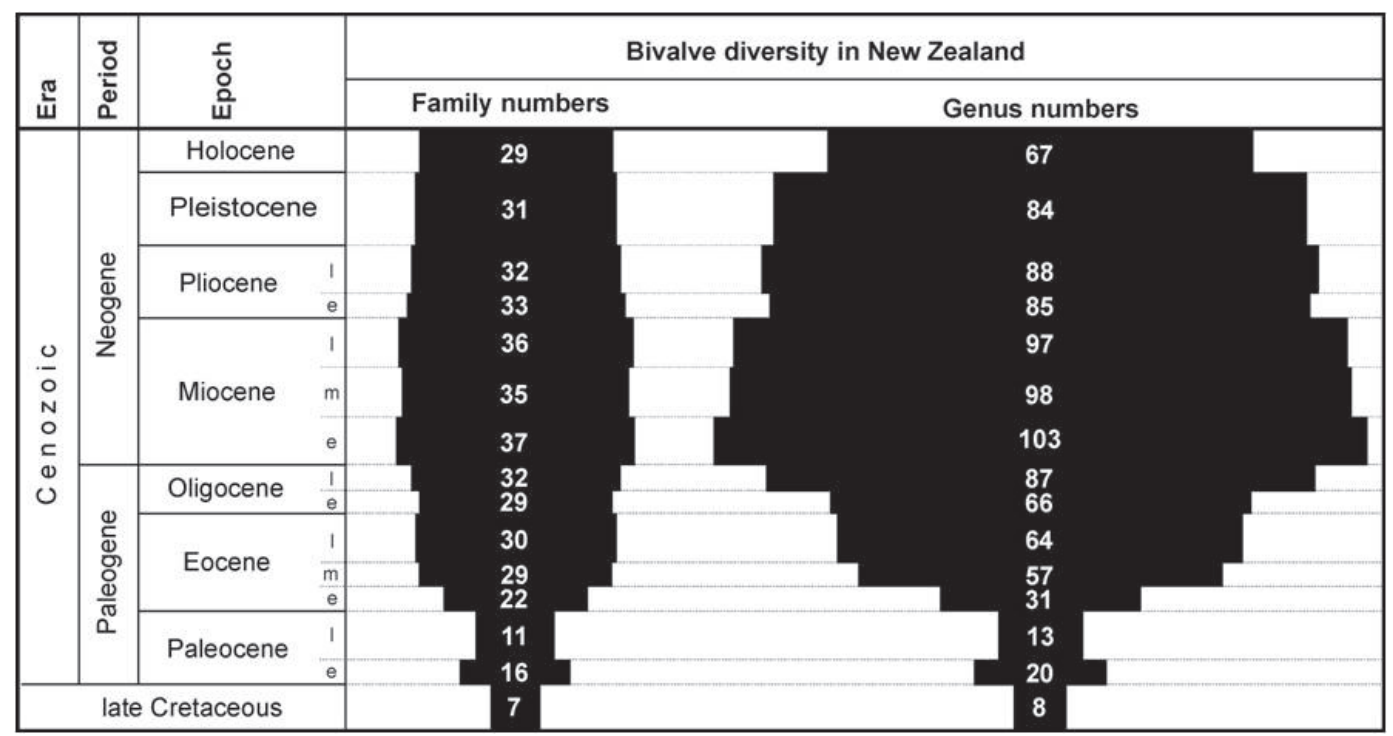

Figure 3. Cenozoic diversity of New Zealand bivalves, according to family and genus numbers (data from Beu \& Maxwell 1990).

According to Beu \& Maxwell (1990), the small number of taxa recorded from the late Cretaceous to the Paleocene would be a consequence of sedimentological conditions that would not favor the preservation during this time interval. Still, marine transgression that initiated from the late Cretaceous and the Paleogene reached its maximum at the end of the Paleogene and the early Neogene, improving the number of recorded taxa from the late Oligocene to the Miocene. Reorganization of marine currents in Southwest Pacific, following the separation of Australia and Antarctica, possibly favored the molluscan dispersal towards New Zealand, including warmer water genera, and shaped the modern diversity in this region.

As another effect following the separation between Australia and Antarctica, Beu \& Maxwell (1990) suggested that restricted basins formation would have promoted speciation, chiefly of molluscan groups with limited dispersal abilities. Most shallow water bivalves of the families Glycymerididae, Limopsidae, Limidae, Pectinidae, Carditidae, Mactridae and Veneridae would have undergone through intensive diversification during the late Oligocene, which would explain the greater number of genera recorded in the early Neogene (Figure 3).

A second important interval in which dispersal would be favored in New Zealand occurred after the middle Miocene, with the Circum-Antarctic Current intensification, following the Drake Passage opening. According to Beu (1985) and Beu et al. (1997), the new oceanic circulation pattern during the Neogene would have allowed the first Circum-Antarctic dispersal event of planktonic molluscan larvae from southern South America to New Zealand.

The same environmental changes that took place after Tasmanian Gateway and Drake Passage openings possibly affected both New Zealand and Antarctic bivalve diversity during the Cenozoic.

According to Table I, intervals with larger recorded family and genera numbers in Antarctica are late Cretaceous, Eocene and Holocene, and secondly, Oligocene. Interestingly, Eocene and Holocene recorded taxa are similar. Considering the idea that the paleontological record is inherently incomplete, those data seem to suggest that the Holocene record is underestimated.

Holocene record in Table I is mostly represented by modern bivalve taxa. In fact, Clarke et al. (2004) estimated that only $25 \%$ of the recent benthic organisms from Antarctica are currently known. In addition, around half of the Eocene Antarctic record is represented in erratic blocks from McMurdo Sound (Figure 1). It is probable that these data are the main cause of the resemblance between Eocene and Holocene records. Fossils recorded in erratic blocks are recycled and, probably, of uncertain age (although attributed to the Eocene by Stilwell 2000). Because of this, only bivalve taxa from the La Meseta Formation represent the Antarctic Eocene record in Figure 2.

Hence, diversity peaks observed in Figure 2 are associated to records from López de Bertodano (late Cretaceous), La Meseta (Eocene) and Polonez Cove 
(Oligocene) formations, as well as the record of Antarctic modern bivalves.

The dynamic of diversity in Figure 2 may reflect three main factors. The first one is related to the scarcity of geological outcrops in Antarctica. The difficult access and the existence of few areas containing cropping rocks in Antarctica are, undoubtedly, the first cause of low sampling in relation to the vast territory. The Antarctic record shown in Table I and illustrated in Figure 2 demonstrates that intervals in which the larger number of recorded bivalve taxa is represented in deposits located in well exposed regions, as in Seymour Island, where deposits from López de Bertodano (Cretaceous) and La Meseta (Eocene) formations are richly fossiliferous.

The second factor would be related to the environmental stress triggered by regional environmental changes following Antarctic cooling. In this case, a record drop since the Oligocene would occur in response to the new environmental conditions established in Antarctica from the Neogene onwards. On the other hand, Beu et al. (1997) suggested that, during intervals of sharp cooling, as occurred in the early Oligocene, speciation events would be favored, resulting in diversity increase. The record reveals, however, a remarkable diversity drop in Miocene to Pleistocene intervals, followed by a significant raise during the Holocene (Figure 2). The sharp diversity oscillation observed in these intervals suggests that the Cenozoic bivalve diversity is extremely underestimate, which points out the scarce knowledge regarding this group in Antarctic throughout the Cenozoic.

Moreover, the diversity pattern illustrated in Figure 2 apparently lacks a general trend associated to the environmental changes that occurred along the Cenozoic, as the Antarctic cooling, which started after the early Oligocene, and the Circum-Antarctic Current establishment, which occurred from the late Oligocene to the middle Miocene (Exon et al. 2001, Eagles \& Livermore 2002, Barker \& Thomas 2004, Pfuhl \& McCave 2005).

To sum up, even though new environmental conditions during the Neogene probably affected the Southern Ocean biodiversity, the currently known Cenozoic record of the Antarctic bivalves does not reflect this influence.

The third factor may be related to the stratigraphic control of deposits, which may enhance recorded taxa during intervals in which depositional conditions (sedimentological and stratigraphic) favor the fossil preservation. According to Holland (1995), the fossil record is stratigraphically controlled. First-appearance peaks match the transgressive system tracts and its limiting surfaces (transgressive surface at the base and maximum flooding surface at the top), while record drops are observed along highstand system tracts, and record absences are linked to lowstand system tracts. Once available descriptions of Cenozoic deposits from Antarctica do not apply the sequence stratigraphy method for geological interpretation, the use of Holland's model (1995) is only an attempt to discuss the Cenozoic bivalve record from Antarctica.

Thus, geological interpretations on stratigraphic sections of the formations deposited during the late Cretaceous, Eocene and Oligocene, would be related to a higher preservation tendency according to distinct facies associations.

In Seymour Island (Figure 1), fossils occur most abundantly at the top of the Lopez de Bertodano Formation (Zinsmeister \& Macellari 1988). In upper portions of the unit, deposits exhibit a retrogradacional trend, as observed in stratigraphic section of Macellari (1988), as well as in geological descriptions of Crame et al. (1991). These deposits may represent transgressive system tracts, suggesting a higher trend in fossil preservation, according to Holland's model (1995). This interpretation would explain the large number of bivalves recorded in the Cretaceous interval (Figure 2).

Around half of bivalve taxa recorded in the Eocene are from the La Meseta Formation (Figure 2). La Meseta Formation deposits cropping out in Seymour Island (Figure 1) are interpreted by Porebski (1995) as originated from valley-estuary filling during succeeding trangressive events related to retrogradacional cycles and also due to rise in sea level caused by tectonics or tectono-eustacy. Bivalve fossils occur in laterally discontinuous sandy lenses along all stratigraphic section, and are more abundant in upper units of the formation (Telm 4, 5 and 6 from Stilwell \& Zinsmeister 1992). These deposits are presented in stratigraphic sections by Elliot \& Trautman (1982) with an aggradational to retrogradational tendency, which is typical of transgressive system tracts. Moreover, these fossiliferous beds are interpreted as tidal bar deposits by Stilwell \& Zinsmeister (1992) and as transgressive 
lags facies by Porebski (1995). Applying Holland's model (1995), those deposits characteristically favor the preservation and, hence, may be related to the high number of Antarctic bivalves recorded to the Antarctic Eocene interval (Figure 2).

The stratigraphic section of the Polonez Cove Formation (Troedson \& Smellie 2002), cropping out at several sites of King George Island (Figure 1), exhibits continental facies increasing towards the top of fossiliferous units, and therefore, a progadacional trend. These deposits may represent highstand system tracts, which would explain the relatively high number of bivalves in the Oligocene interval (Figure 2), according to Holland's model (1995).

However, depositional systems affected by glacial events may show smaller order cycles of sea level rise and fall, which would imply limited variations of the preserved taxa number in specific stratigraphic level (Eyles \& Eyles 1992). Thus, the use of Holland's model (1995) is viable in cases of high-resolution faciologic and cycle-stratigraphic controls, when it is possible to delimit architectural surfaces and tendencies of minor order.

\section{SUMMARY AND FUTURE RESEARCHES}

1) The rises and drops observed in Cenozoic Antarctic bivalve diversity may reflect the rare available outcrops for research in Antarctica. The majority of Cenozoic bivalve taxa recorded in the entire continent are restricted to the few outcrops in Antarctic Peninsula islands.

2) Apart from few Antarctic areas with well exposed outcrops, the high number of recorded bivalve taxa in some Cenozoic intervals may be related to the stratigraphic control of deposits. Fossiliferous deposits of the late Cretaceous, Eocene and Oligocene exhibit sedimentological characteristics probably indicative of higher tendency in fossil preservation.

3) The Cenozoic diversity pattern of Antarctic bivalve genera apparently lacks a general trend associated to the Cenozoic environmental changes. Although new environmental conditions during the Neogene probably affected the Southern Ocean biodiversity, the currently known Cenozoic record of the Antarctic bivalves does not reflect this influence.

4) As the currently known Cenozoic record of Antarctic bivalves is scarce and does not reflect
Cenozoic environmental changes, other researches should be achieved in order to study the effects of the Cenozoic climatic changes on Antarctic bivalve diversity. Other possibilities are to analyze the Cenozoic distribution of other invertebrate marine taxa, or even to assess the bivalve paleobiogeographic distribution in Antarctica and in other Southern Ocean regions to evaluate possible dispersal events coupled with major environmental changes in the Southern Ocean.

\section{REFERENCES}

ANELLI, L.E.; ROCHA-CAMPOS, A.C.; SANTOS, P.R.; PERINOTTO, J.A.J. \& QUAGLIO, F. 2006. Early Miocene bivalves from the Cape Melville Formation, King George Island, West Antarctica. Alcheringa, 30: 111-132.

BARKER, P.F. \& THOMAS, E. 2004. Origin, signature and paleoclimatic influence of the Antarctic Circumpolar Current. Earth Science Review, 66: 143-162.

BARTEK, L.R.; SLOAN, L.C.; ANDERSON, J.B. \& ROSS, M.I. 1992. Evidence from the Antarctic continental margin of Late Paleogene ice sheets: a manifestation of plate reorganization and synchronous changes in atmospheric circulation over the emerging Southern Ocean? Pp 131-159. In: D.R. Protheno \& W.A. Berggren, (eds.), Eocene-Oligocene Climatic and Biotic Evolution. Princeton University Press, Princeton.

BEU, A.G. 1985. Pleistocene Chlamys patagonica delicatula (Bivalvia: Pectinidae) off southeastern Tasmania and history of its species group in the Southern Ocean. Department of Mines and Energy, South Australia, Special Publication, 5: $1-11$.

BEU, A.G. \& MAXWELL, P.A. 1990. Cenozoic Mollusca of New Zealand. New Zealand Geological Survey Paleontological Bulletin, 58: 518 pp.

BEU, A.G.; GRIFFIN, M. \& MAXWELL, P.A. 1997. Opening of Drake Passage gateway and Late Miocene to Pleistocene cooling reflected in Southern Ocean molluscan dispersal: evidence from New Zealand and Argentina. Tectonophysics, 281: 83-97.

CLARKE, A.; ARONSON, R.B.; CRAME, J.A.; GILI, J.M. \& BLAKE, D.B. 2004. Evolution and diversity of the benthic fauna of the Southern Ocean continental shelf. Antarctic Science, 16 (4): 559-568.

CRAME, J.A.; PIRRIE, D.; RIDING, J.B. \& THOMSON, M.R.A. 1991. Campanian-Maastrichtian (Cretaceous) stratigraphy of the James Ross Island area, Antarctica. Journal of the Geological Society, London, 148: 1125-1140.

DECONTO, R.M. \& POLLARD, D. 2003a. Rapid Cenozoic 
glaciation of Antarctica induced by declining atmospheric $\mathrm{CO}_{2}$. Nature, 421: 245-249.

DECONTO, R.M. \& POLLARD, D. 2003b. A coupled climateice sheet modeling approach to the Early Cenozoic history of the Antarctic ice sheet. Paleogeography, Paleoclimatology, Paleoecology, 37: 53-81.

EAGLES, G. \& LIVERMORE, R.A. 2002. Opening history of Powell Basin, Antarctic Peninsula. Marine Geology, 185: 195205.

ELLIOT, D.H. \& TRAUTMAN, D.E. 1982. Lower Tertiary strata on Seymour Island, Antarctic Península. Pp 287-297. In: C. Craddock, (ed.), Antarctic Geosciences. University of Wisconsin Press, Madison.

EXON, N.F.; KENNETT, J.P.; MALONE, M.J.; BRINKHUIS, H.; CHAPRONIERE, G.C.H.; ENNYU, A.; FOTHERGILL, P.; FULLER, M.D.; GRAUERT, M.; HILL, P.J.; JANECEK, T.R.; KELLY, D.C.; LATIMER, J.C.; NEES, S.; NINNEMANN, U.S.; NUERNBERG, D.; PEKAR, S.F.; PELLATON, C.C.; PFUHL, H.A.; ROBERT, C.M.; ROESSIG, K.L.; ROEHL, U.; SCHELLENBERG, S.A.; SHEVENELL, A.E.; STICKLEY, C.E.; SUZUKI, N.; TOUCHARD, Y.; WEI, W. \& WHITE, T.S. 2001. The Tasmanian Gateway: Cenozoic climatic and oceanographic development, sites 1168-1172. Proceedings of the Ocean Drilling Program, Initial Reports, 189: 98p.

EYLES, N. \& EYLES, C.H. 1992. Glacial depositional systems. Pp 73-100 In: R.G. Walker \& N.P. James, (eds.), Facies models: response to sea level change. Geological Association of Canada, Ontario.

GAŹDZICKI, A. \& PUGACZEWSKA, H. 1984. Biota of the “Pecten conglomerate” (Polonez Cove Formation, Pliocene) of the King George Island (South Shetland Islands, Antarctica). Studia Geologica Polonica, 79: 59-120.

HOLLAND, S.M. 1995. The stratigraphic distribution of fossils. Paleobiology, 21: 92-109.

JONKERS, H.A. 2003. Late Cenozoic-Recent Pectinidae (Mollusca: Bivalvia) of the Southern Ocean and neighbouring regions. Monographs of Marine Mollusca, 5: 125 pp.

LIVERMORE, R.; EAGLES, G.; MORRIS, P. \& MALDONADO, A. 2004. Shackleton Fracture Zone: no barrier to early circumpolar ocean circulation. Geology, 32 (9): 797-800.

MACELLARI, C.E. 1988. Stratigraphy, sedimentology and paleoecology of Upper Cretaceous/Paleocene shelf deltaic sediments of Seymour Island. In: R. M. Feldmann \& M. O.Woodburne, (eds.), Geology and paleontology of Seymour Island, Antarctica Peninsula. Geological Society of America, Memoir, 169: 253-284.

PFUHL, H. A. \& MCCAVE, I.N. 2005. Evidence for late Oligocene establishment of the Antarctic Circumpolar
Current. Earth and Planetary Science Letters, 235: 715-728. POREBSKI, S.J. 1995. Facies architecture in a tectonicallycontrolled incised-valley estuary, La Meseta Formation (Eocene) of Seymour Island, Antarctic Peninsula. Studia Geologica Polonica, 107: 7-96.

PUGACZEWSKA, H. 1984. Tertiary Bivalvia and Scaphopoda from glaciomarine deposits at Magda Nunatak, King George Island (South Shetlands Island, Antarctica). Studia Geologica Polonica, 79: 53-58.

QUAGLIO, F.; ANELLI, L.E.; SANTOS, P.R.; PERINOTTO, J.A.J. \& ROCHA-CAMPOS, A.C. In press. Invertebrates from the Low Head Member (Polonez Cove Formation, Oligocene) at Vauréal Peak, King George Island, West Antarctica. Antarctic Science.

SOMBASE (SOUTHERN OCEAN MOLLUSC DATABASE). Database created in 2004 by the British Antarctic Survey and coordinate by H. J. Griffths. <http://www.antarctica. ac.uk/BAS_Science/programmes2000-2005/ABPPF/ SOMBASE/>. Accessed in jun. 2007.

STILWELL, J.D. 2000. Eocene Mollusca (Bivalvia, Gastropoda and Scaphopoda) from McMurdo Sound: systematics and paleoecologic significance. Antarctic Research Series, 76: 261-320.

STILWELL, J.D. 2002. Geological exploration of Cockburn Island, Antarctic Peninsula. Polish Polar Research, 23(1): 47-73.

STILWELL, J.D. 2003. Patterns of biodiversity and faunal rebound following the K-T boundary extinction event in Austral Paleocene molluscan faunas. Palaeogeography, Palaeoclimatology, Palaeoecology, 195: 319-356.

STILWELL, J.D. \& ZINSMEISTER, W.J. 1987. Late Cretaceous fossils from Cockburn Island collected during the 1986-1987 expedition to the Antarctic Peninsula. Antarctic Journal of the United States, 22 (5): 5-6.

STILWELL, J.D. \& ZINSMEISTER, W.J. 1992. Molluscan systematics and biostratigraphy. Lower Tertiary La Meseta Formation, Seymour Island, Antarctic Peninsula. Antarctic Research Series, 55: 192pp.

STILWELL,J.D.\&ZINSMEISTER,W.J.2000.Paleobiogeographic synthesis of the Eocene macrofauna from McMurdo Sound, Antarctica. Antarctic Research Series, 76: 365-372.

STILWELL, J.D.; ZINSMEISTER, W.J. \& OLEINIK, A.E. 2004. Early Paleocene mollusks of Antarctica: systematics, paleoecology and paleobiogeographic significance. Bulletins of American Paleontology, 367: 89 p.

STUDENKA, B. 1991. A new species of genus Panopea (Bivalvia) from the King George Island, Antarctica. Polish Polar Research, 12 (3): 363-368.

TRIPATI, A.; BACKMAN, J.; ELDERFIELD, H. \& FERRETTI, 
P. 2005. Eocene bipolar glaciation associated with global carbon cycle changes. Nature, 436: 341-346.

TROEDSON, A.L. \& SMELLIE, J.L. 2002. The Polonez Cove Formation of King George Island, Antarctica: stratigraphy, facies and implications for mid-Cenozoic cryosphere development. Sedimentology, 49: 277-301.

ZACHOS, J.; PAGANI, M.; SLOAN, L.; THOMAS, E. \& BILLUPS, K. 2001. Trends, rhythms, and aberrations in Global Climate 65 Ma to Present. Science, 292: 686-693.

ZINSMEISTER, W.J. 1982. Late Cretaceous-Early Tertiary molluscan biogeography of the Southern Circum-Pacific. Journal of Paleontology, 56 (1): 84-102.

ZINSMEISTER, W.J. 1984. Late Eocene bivalves (Mollusca) from the La Meseta Formation, collected during the 197475 joint Argentine-American expedition to Seymour Island, Antarctic Peninsula. Journal of Paleontology, 58: 14971527.

ZINSMEISTER, W.J. \& MACELLARI, C.E. 1988. Bivalvia (Mollusca) from Seymour Island, Antarctic Peninsula. In: R. M. Feldmann \& M. O.Woodburne, (eds.), Geology and paleontology of Seymour Island, Antarctica Peninsula. Geological Society of America, Memoir, 169: 253-284.

Submetido em 30/08/2007.

Aceito em 12/09/2007. 